\title{
An Evaluation of the Whole Effluent Toxicity Test Method
}

by

D. V. Osteen

Westinghouse Savannah River Company

Savannah River Site

Aiken, South Carolina 29808

W. L. Specht

D. E. Gordon

L. L. Eldridge

This paper was prepared in connection with work done under the above contract number with the U.S.

Department of Energy. By acceptance of this paper, the publisher and/or recipient acknowledges the U. S.

Government's right to retain a nonexclusive, royalty-free license in and to any copyright covering this paper, along with the right to reproduce and to authorize others to reproduce all or part of the copyrighted paper. 


\section{DISCLAIMER}

This report was prepared as an account of work sponsored by an agency of the United States Government. Neither the United States Government nor any agency thereof, nor any of their employees, makes any warranty, express or implied, or assumes any legal liability or responsibility for the accuracy, completeness, or usefulness of any information, apparatus, product or process disclosed, or represents that its use would not infringe privately owned rights. Reference herein to any specific commercial product, process or service by trade name, trademark, manufacturer, or otherwise does not necessarily constitute or imply its endorsement, recommendation, or favoring by the United States Government or any agency thereof. The views and opinions of authors expressed herein do not necessarily state or reflect those of the United States Government or any agency thereof.

This report has been reproduced directly from the best available copy.

Available for sale to the public, in paper, from: U.S. Department of Commerce, National Technical Information Service, 5285 Port Royal Road, Springfield, VA 22161

phone: (800) 553-6847

fax: (703) 605-6900

email: orders@ntis.fedworld.gov

online ordering: http://www.ntis.gov/ordering.htm

Available electronically at http://www.doe.gov/bridge

Available for a processing fee to U.S. Department of Energy and its contractors, in paper, from: U.S. Department of Energy, Office of Scientific and Technical Information, P.O. Box 62, Oak Ridge, TN 37831-0062

phone: (865)576-8401

fax: (865)576-5728

email: reports@adonis.osti.gov 


\section{DISCLAIMER}

Portions of this document may be illegible in electronic image products. Images are produced from the best available original document. 


\section{An Evaluation of the Whole Effluent Toxicity Test Method}

by

D. Vernon Osteen Winona L. Specht

Donald E. Gordon

Larry L. Eldridge

Westinghouse Savannah River Company LLC Savannah River Site Aiken, South Carolina 29808
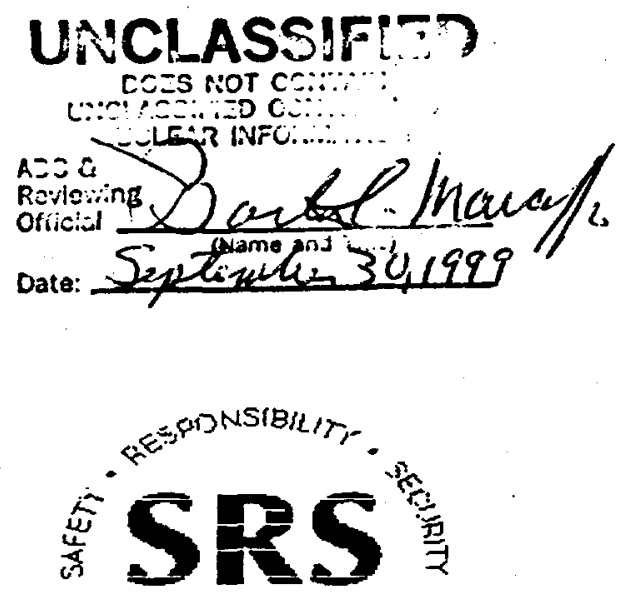


\section{AN EVALUATION OF THE WHOLE EFFLUENT TOXICITY TEST METHOD}

\section{EXECUTIVE SUMMARY}

Toxicity testing has been incorporated into the strategy of National Pollutant Discharge Elimination System (NPDES) permitting by the Environmental Protection Agency (EPA) for the protection of aquatic life in streams which receive industrial wastewater effluent. The basic premise of this strategic approach is to predict the effect of an effluent on aquatic life in a receiving stream by observing the impact of the effluent on a test organism. The test method must reflect representative conditions in order for the results to accurately and reproduceably project valid stream impacts. Several questions have been raised in regards to the accuracy and reliability of the standard toxicity test method as adopted by EPA. This paper presents the Savannah River Site position that the EPA test is neither reasonable nor accurate and thus can not adequately establish the impact of NPDES outfall discharges on receiving streams.

Toxicity testing was first introduced at SRS as a NPDES permit requirement on the Central Sanitary Wastewater Treatment Facility in 1995. In the following year, toxicity permit limits were set at four other NPDES outfalls. The toxicity tests conducted at these five NPDES outfalls have yielded a variety of results. One consistent observation was the failure of the tests because of mortality and/or non-reproducibility of the standard test organism, Ceriodaphnia dubia, in both the effluent and control waters. Moderately hard standard control water and water from a site stream were used for control and dilution purposes. On several occasions, the outfall effluent failed the toxicity test and a Toxicity Identification Evaluation (TIE) was initiated. However, the toxicity of the effluent sample was not toxic enough for the TIE to proceed.

The standard test organism for whole effluent toxicity (WET) testing is $C$. dubia. The suitability of $C$. dubia as adopted by EPA for toxicity testing has come into question. This organism survives and reproduces well in high hardness water but experiences stress when subjected to low hardness water. The hardness of natural waters at SRS is quite low and is thought to be the major cause of acute and chronic failures during toxicity testing of site outfall effluents. The open literature indicates that the accuracy and reliability of the standard toxicity test method can not be determined. False positives and false negatives have been documented as high as $35-40 \%$.

SRS submitted a proposal to the South Carolina Department of Health and Environmental Control and EPA for using an alternate species, Daphnia ambigua, in toxicity tests where low hardness waters are prevalent. D. ambigua has been shown to be as sensitive to chronic and acute reference toxicants as the standard test organism, $C$. dubia. EPA is waiting on internal guidance before rendering an opinion on the alternate species proposal. Concerns have been expressed by third parties over the accuracy and reliability of the WET test method. Under a recent Settlement Agreement, EPA is required to conduct a more rigorous evaluation of the test method. Based on site experience and literature reviews, SRS contends that the current WET method is not appropriate for use 
in soft water environments, therefore should not be used as the basis for a pass-fail permit condition. SRS recommends that results from the standard WET method be treated as monitor and report until a more reliable and accurate test can be developed.

\section{INTRODUCTION}

Whole effluent toxicity (WET) testing has become increasingly more important to the Environmental Protection Agency (EPA) and the States in the permitting of wastewater discharges from industry and municipalities. The primary purpose of the WET test is to protect aquatic life by predicting the effect of an effluent on the receiving stream. However, there are both scientific and regulatory concerns that using WET tests to regulate industrial effluents may result in either false positives and/or false negatives (Parkhurst 1996). In order to realistically predict the effect of an effluent on the receiving stream, the test should be as representative as possible of the conditions in the receiving stream. Studies (Rand and Petrocelli 1985) suggested several criteria for an ideal aquatic toxicity test organism, one of which is that the organism be indigenous to, or representative of, the ecosystem receiving the effluent. The other component needed in the development of a predictive test is the use of the receiving stream water or similar synthetic water as the control and dilution water in the test method. Use of an indigenous species and receiving water in the test should help reduce the variability in the method and allow the test to predict the effect of the effluent on the receiving stream.

The experience with toxicity testing at the Savannah River Site (SRS) has yielded inconclusive data because of the inconsistency and unreliability of the results. The SRS contention is that the WET method in its present form does not adequately mimic actual biological/chemical conditions of the receiving streams and is neither reasonable nor accurate. This paper discusses the rationale for such a position by SRS on toxicity testing in terms of historical permitting requirements, outfall effluent test results, standard test method evaluation, scientific review of alternate test species, and concerns over the test method expressed by other organizations.

\section{HISTORICAL PERMITTING REQUIREMENTS}

Implementation of the WET approach at SRS began in 1995 with toxicity requirements in the National Pollutant Discharge Elimination System (NPDES) Permit \#SC0044903 for the Central Sanitary Wastewater Treatment Facility (CSWTF) at outfall G-10. The initial requirements were monthly acute and chronic toxicity testing at outfall G-10.

During the 1996 negotiation of the NPDES Permit \#SC0000175, the South Carolina Department of Health and Environmental Control (SCDHEC) began to take an in-depth look at implementing toxicity requirements in SRS NPDES permits. 
NPDES Permit \#SC0000175 became effective on October 1, 1996, and imposed toxicity requirements on outfalls A-01, A-11, G-10, and X-08. The permit was later modified to include toxicity requirements for outfall $\mathrm{X}-19$. The CSWTF outfall, G-10, continued to have toxicity limits for acute and chronic tests as in the previous permit mentioned earlier. The only change was the reduction of the instream waste concentration (IWC) for the chronic toxicity test from $25 \%$ to $19 \%$. The acute toxicity test remained at $100 \%$ of IWC. Outfalls A-01 and A-11 received monitor and report requirements when the permit was issued. A special condition in the permit required a compliance schedule for outfall A-01 to meet toxicity limits as well as other parameters by October 1, 1999. Outfall A-11 initially had a monitor and report requirement until 12 consecutive months of acceptable toxicity data had been demonstrated. However, in the January 1998 modification to the NPDES permit, a toxicity limit was imposed for outfall A-11 to be effective on September 30, 1998. Outfall X-08 had a one-time acute toxicity test limit to be met within six months after full operation of the air stripper used for groundwater remediation of the area had been achieved.

During the 1996 negotiations, SRS successfully negotiated with SCDHEC to allow the Site to use receiving stream water for control water at outfalls A-01 and A-11. SCDHEC agreed with SRS that the test should address the question of how an effluent impacts the receiving stream. Since both outfalls form the headwaters of Tims Branch, an alternative receiving stream, Upper Three Runs (UTR), had to be designated for these outfalls for testing purposes. SRS provided ambient water quality data from UTR upstream of all discharges from the Site and confirmed that no industrial wastewaters are discharged upstream of the alternate control water location. Information about the high quality of macroinvertebrate life in UTR was also provided to SCDHEC.

To provide further options for establishing a more representative test, the Site successfully negotiated an additional special permit condition with SCDHEC for consideration of an alternate species for toxicity testing. The Savannah River Technology Center (SRTC) has conducted an alternate species study (Specht and Harmon 1997) to compare Ceriodaphnia dubia to an indigenous species, Daphnia ambigua. As discussed later, D. ambigua appears to be a promising alternate species.

\section{OUTFALL TEST RESULTS AND SOURCE INVESTIGATIONS}

The results of compliance toxicity testing are discussed in this section along with investigations conducted to determine the source of toxicity where the WET tests failed. 


\section{Outfall A-01}

As allowed by the permit, the Site used moderately hard standard control water and/or UTR water as controls for outfall A-01 chronic toxicity testing. During the 33 months since the issuance of the permit, 51 compliance toxicity tests (Attachment A) have been conducted in which 20 used standard control water and 31 used UTR control water. Of the 51 compliance tests, only the May 1999 test met the minimum criteria (mean of 15 young per surviving adult) for a valid test and passed. Standard control water was used during this test. During all of the testing, mortality in the effluent was observed to be from $0 \%$ in two tests to $100 \%$ in 21 tests. The reproduction in the effluent ranged from 0 to 22.4 average young per adult. There were only 5 tests that produced greater than 15 average young per adult in the effluent. The toxicity tests using UTR water as the control have only met the minimum criteria for a valid test in April 1999. After observing $100 \%$ mortality in the UTR control water in March 1998, either dual controls (UTR and standard lab water) or standard lab water has been used during testing to try to obtain a valid test. Since the issuance of the permit, the Site studied the compliance issues at outfall A-01 and had a 3-year compliance schedule to develop a solution. The parameters of concern at A-01 are toxicity, copper, lead, mercury, and residual chlorine. During the studies to resolve the compliance issues, the Site completed a toxicity identification evaluation (TIE) on the effluent. The TIE indicated that the toxicity problem is related to the copper levels, which are high enough that toxicity would be expected. Preliminary confirmation studies indicate that the toxicity at the outfall will be eliminated with a constructed wetland treatment facility, which was selected from other treatment options extensively analyzed. Additional confirmation studies are currently being conducted to ensure that all of the parameters in question will be in compliance.

\section{Outfall A-11}

As allowed by the permit, the Site used moderately hard standard control water and/or UTR water as controls for outfall A-11 chronic toxicity testing. During the 33 months since the issuance of the permit, 43 compliance toxicity tests (Attachment B) have been conducted in which 21 tests used standard control water and 22 tests used UTR control water; 19 tests of the 42 passed. Of these passes, 4 tests used standard control water and 15 tests used UTR control. Thirteen of the 15 passes using UTR control water did not meet minimum reproduction in the control. The other 2 toxicity tests using UTR water as the control did meet the minimum criteria. Mortality in the effluent samples ranged from $5 \%$ to $85 \%$. Reproduction in the effluent ranged from a mean 0 to 24.15 young per adult. After observing $100 \%$ mortality in the UTR control water in March 1998, either dual controls (UTR and standard lab water) or standard lab water has been used during testing to try to obtain a valid test. In November 1996, the first toxicity test failed invoking a special condition in the permit requiring development of a toxicity evaluation plan (TEP) with submittal to SCDHEC within 60 days. An investigation to identify the potential toxicity problem at outfall A-11 was conducted. Preliminary results indicated that the 
toxicity could be coming from the Vendor Treatment Facility (VTF), which discharges to a substream to outfall A-11. In July 1997, the final TEP report stated that a corrosion inhibitor would alleviate the problem at A-11. However, the VTF discharge ceased for facility repair, and the outfall began to pass toxicity tests. It was deemed unnecessary to install a permanent system to inject corrosion inhibitor at that time. If a future test failure is experienced at A-11, then a TIE would be performed to resolve any subsequent toxicity problems. The toxicity issue was considered resolved with the issuance of the final TEP in July 1997. After a subsequent failure at outfall A-11 in April 1998, the Site reactivated the TEP and began again to investigate the cause of the potential toxicity. Numerous toxicity tests were conducted on substreams of outfall A-11 to pinpoint the location of the source of the toxicity and narrow the scope of the investigation. Once the TIE was initiated, results from various analytical techniques indicated that the toxicant was filterable. Upon completion of Phase I of the TIE, preliminary results indicated that iron and aluminum were present at high concentrations, which could be a contributor to toxicity. Even with increased sampling, the Site had difficulty obtaining a sample toxic enough to complete Phase II and Phase III and finalize the TIE, while the compliance testing at outfall A-11 continued to fail. In April 1999, a sample was obtained with sufficient toxicity to continue with Phase II and III of the TIE. However, iron and aluminum concentrations in this sample were low, and therefore, the earlier pattern of toxicity could not be confirmed. The new results indicated that the source was related to chlorine and an unfilterable toxicant. The Site is continuing to investigate the cause of toxicity.

Outfall A-11 passed the toxicity test for the period of May to July 1999. The toxicity at outfall A-11 has apparently disappeared. However, due to history of toxicity at outfall A-11, the Site will continue a strategy to determine the cause of toxicity in case the compliance sample fails. Extra water from the compliance samples will be held until toxicity for the sample has been determined. If it is toxic, a TIE will be run on the remainder of the sample.

As evidenced by the outfall A-11 toxicity data from October 1996 to July 1999, the variability in the toxicity data and the difficulty in obtaining sufficiently toxic samples for completion of the TIE exemplify the concerns with the toxicity test protocols. It has been very difficult to determine the cause of the toxicity problem due to the dynamic conditions encountered at outfall A-11, the inability to obtain a toxic enough sample, and the inconsistency of the test results.

\section{Outfall G-10}

The CSWTF went on-line in May 1995 with monthly chronic and acute toxicity testing requirements in the NPDES permit. Outfall G-10 is the discharge point from the sewage treatment facility into Fourmile Branch. Under the original NPDES permit, the outfall performed well and passed the acute and the chronic toxicity tests from June 1995 until 
December 1995. However, in January 1996, both the acute and chronic tests failed triggering a TEP for investigating the cause of the toxicity. Extensive toxicity testing revealed that the condition was intermittent. Because of this intermittent condition, determining the source of the toxicity failure has been very difficult. The approved TEP states that if no toxicity failures occur, the investigation is discontinued until there is another failure. The outfall immediately began to pass the acute and chronic tests in February 1996. When the NPDES permit was renewed in October 1996, both acute and chronic toxicity requirements remained for outfall G-10, and the outfall continued to pass both. After establishing a record of over 12 consecutive months of passes and as allowed by the permit, SRS petitioned SCDHEC in April 1997 to eliminate the toxicity testing. SCDHEC modified the NPDES permit in June 1997 to reduce the toxicity sampling to twice per year.

However, in August 1998, both the acute and chronic compliance tests failed again and the TEP was reactivated. This second round of investigations included toxicity samples and metals analysis on process control samples to try to identify the source of the toxicity. All of the process control samples exhibited no toxic effects, which hampered the investigation of the cause of the toxicity. Although the toxicity is very intermittent, the Site continues to take process control samples (Attachment $\mathrm{C}$ ) on a monthly basis. Subsequent compliance toxicity samples have passed.

\section{Outfall X-08}

The 1996 NPDES permit required that the effluent at outfall X-08 be tested on a one-time basis for acute toxicity at $100 \%$ of IWC. If a failure occurred, then a Toxicity Reduction Plan (TRP) would be completed to resolve the problem. In December 1996, the acute toxicity test failed and a TRP was prepared. The investigation of the problem was initiated and a Toxicity Identification Evaluation (TIE) identified the source of the toxicity as zinc. Further investigation revealed the source of zinc as galvanized piping in the air stripper system. The corrective action for eliminating the source of toxicity was to replace the galvanized pipe and clean out sludge in the Effluent Treatment Plant clarifier. A confirmatory toxicity test demonstrated that the corrections had eliminated the toxicity at the outfall. A toxicity test with an IWC of $33 \%$ was deemed appropriate from the mixing zone modeling, CORMIX3, which indicated that there would be no impact to the Savannah River at this concentration. Even with the corrective actions completed, SCDHEC modified the NPDES permit to impose monthly acute toxicity testing at $33 \%$ of IWC effective as of January 1998. Based on the permit condition, SRS recorded 12 consecutive months of passes and requested in February 1999 that the toxicity requirement be eliminated. This request is currently under consideration by SCDHEC in the revoke/reissue permit, and the monthly toxicity testing has been removed from the draft permit. 


\section{Outfall X-19}

In the NPDES permit modification effective on January 1, 1998, an acute toxicity limit was placed on the discharge of treated groundwater at outfall X-19. The Site's mixing zone demonstration, based on CORMIX3 model, indicated that with the IWC at 33\% there would be no impact to the Savannah River. Consequently, SCDHEC imposed a monthly acute toxicity test with an IWC of 33\%. All toxicity tests have passed. With the completion of twelve consecutive passes when X-19 is discharging, SRS will propose the elimination of the toxicity limit.

\section{EVALUATION OF CURRENT TOXICITY METHOD}

The suitability of Ceriodaphnia dubia as a standard test organism for WET testing in all freshwaters in all situations needs to be evaluated to ensure that the analysis is reflective of the receiving stream. The following section will discuss the appropriateness of $C$. dubia as a test organism for very soft waters at SRS, the ability of the WET test to predict potential stream impact, and variability in the current test method.

In an effort to resolve problems encountered using the established procedure, SRS conducted a study (Specht and Harmon 1997) to evaluate an alternate species that would have the same or greater sensitivity to toxicants as $C$. dubia and that survives and reproduces in receiving stream water. The chemical composition of surface waters in the United States varies widely with respect to water hardness and trace mineral content. Water hardness in the United Sates ranges from near $0 \mathrm{mg} / \mathrm{L}$ to more than $1000 \mathrm{mg} / \mathrm{L}$ (Hem 1985). For the sake of consistency but despite huge differences in water chemistry, the EPA chose one species of daphnid, $C$. dubia, for use in chronic toxicity tests nationwide.

SRS waters, like many southeastern coastal plain streams, are extremely soft with hardness ranging from approximately 2 to $30 \mathrm{mg} / \mathrm{L}$. Very soft waters can be stressful to organisms that are not adapted to them due to osmotic stress (water tends to diffuse into the organisms faster than it can be excreted). In addition, crustaceans, such as $C$. dubia, incorporate some calcium into their exoskeletons; therefore, low hardness water would cause stress in these organisms.

Some species of aquatic life are well adapted to very soft waters, as evidenced by the large number of macroinvertebrate species found in UTR. At least 653 species of aquatic insects have been collected from UTR (Morse 1999), more than have been reported for a stream of any size anywhere in the world. Pen Branch also contains a remarkably diverse fauna with at least 281 species of aquatic insects reported to date (Morse 1999). Fourmile Branch is less diverse, probably because its naturally acidic water and high concentrations of iron that exceed the physiological tolerance of many aquatic species. 
Two of these three SRS streams contain high quality macroinvertebrate communities. However, studies funded by SRS and conducted by an independent contract laboratory have shown that none of these three streams is capable of supporting cultures of $C$. dubia for extended periods of time.

In 1994, ETT Environmental, a SCDHEC-certified laboratory in Greenville, SC, attempted to maintain cultures of $C$. dubia for up to 12 months in water collected from UTR, Fourmile Branch, and Pen Branch at locations that were upstream from any SRS effluent or stormwater discharges. In addition, chronic toxicity tests were performed monthly on the stream waters. These tests compared the reproductive rates of $C$. dubia cultured in these SRS waters to $C$. dubia cultured in dilute mineral water. The results of the study (Specht 1995) indicated that the water from all three streams exhibited varying degrees of toxicity, with Pen Branch being the least toxic (no acute toxicity; chronic toxicity in 5 of 11 months), UTR being intermediate (acute toxicity in 6 of 11 months; chronic toxicity in 10 of 10 months), and Four Mile Branch being the most toxic (cultures could not be maintained long term; acute toxicity in 3 of 5 months; chronic toxicity in 5 of 5 months). The results of reference toxicant tests using sodium chloride also indicated that the LC50s of the Ceriodaphnia cultured in SRS waters were consistently lower than those of Ceriodaphnia cultured in dilute mineral water. The results of the reference toxicant tests indicate that the daphnids cultured in SRS waters were somewhat stressed by the SRS waters, and therefore, overly sensitive to the effects of a toxicant.

Table 1 contains the mean and range of hardness and $\mathrm{pH}$ values reported during the yearlong study. As can be seen in the table, the hardness of UTR averages less than $5 \mathrm{mg} / \mathrm{L}$, while that of Pen Branch averages almost $20 \mathrm{mg} / \mathrm{L}$. The hardness of SRS streams increases from west to east, due to calcareous deposits closer to the surface in the eastern part of the Site. It is likely that the difference in hardness was largely responsible for the increased survival and reproduction in the toxicity tests that were conducted in Pen Branch as compared to UTR.

Table 1. Hardness and pH Values for Three SRS Streams

\begin{tabular}{|l|l|l|l|l|l|l|}
\cline { 2 - 7 } \multicolumn{1}{c|}{} & \multicolumn{2}{l|}{ Upper Three Runs } & \multicolumn{2}{l|}{ Fourmile Branch } & \multicolumn{2}{l|}{ Pen Branch } \\
\hline Parameter & Mean & Range & Mean & Range & Mean & Range \\
\hline Hardness & 4.4 & $1.9-8.0$ & 12.9 & $8.0-23.3$ & 19.6 & $12.0-30.9$ \\
\hline pH & 5.7 & $5.2-7.4$ & 5.3 & $4.5-5.9$ & 6.7 & $6.1-7.4$ \\
\hline
\end{tabular}

As a follow-up to this study, TIEs were conducted on C. dubia using water collected from the same locations on Fourmile Branch (Road F) and UTR (Road 8-1) as were sampled in the 1994 study. Both of these locations are upstream of all SRS discharges to 
the streams. The results of the TIE conducted on Fourmile Branch indicated that the toxicity was due primarily to naturally occurring iron, which was found at a concentration of up to $6.2 \mathrm{mg} / \mathrm{L}$ (ETT Environmental 1995, Specht and Kelley 1998), and also to intermittently low $\mathrm{pH}(<5)$. The TIE on UTR was never completed due to intermittent toxicity, but the results indicated that the toxicity was usually greatest after periods of heavy rain and that the toxicant was removed by aeration at $\mathrm{pH} 3$. The results indicate that the toxicant is either volatile or oxidizable when exposed to low pH. ETT Environmental concluded that it was likely that the toxicity was due to naturally occurring humic acids that entered the stream from the surrounding swampy floodplain during periods of heavy rain.

The results of these toxicity studies suggest that $C$. dubia is an inappropriate species for assessing toxicity of SRS effluents. This species is not native to the southeastern coastal plain. The studies indicate that this species cannot survive in unimpacted SRS surface waters that are capable of supporting extremely diverse aquatic life, and that it does poorly in very soft water. Most SRS effluents contain large amounts of groundwater that are also very soft. Therefore, if $C$. dubia is used in toxicity tests of SRS effluents and/or receiving streams, it is not possible to distinguish between toxicity due to the presence of a toxicant or stress resulting from exposure to very soft water. In addition, it is likely that exposure to the extremely soft water produces physiological stress in C. dubia, and therefore, makes the test organisms overly sensitive to the effects of toxicants that may be present in the effluents.

The previous discussion that $C$. dubia is not the appropriate species for very soft waters only lends credence to the assertion that the WET test method is not predictive of the condition in the receiving stream. According to studies (Parkhurst 1996), the "...historical validation studies may not have much relevance for predicting effects of effluent on aquatic life today." At SRS, the ability of the WET method to predict a receiving stream condition is brought into question when the toxicity test results at NPDES outfalls are compared to the biological assessment (Specht and Paller 1998) performed on their receiving streams. WET test failures occurred at outfalls A-01 and A-11 which discharge into Tims Branch, and outfall G-10 which discharges into Fourmile Branch. Although outfalls A-01, A-11, and G-10 failed the WET method on several occasions, the biological assessment indicates that Tims Branch and Fourmile Branch were unimpacted. Diamond et al. (1999) evaluated WET testing and stream impairment on over 250 municipal and industrial facilities and found that the chronic and acute WET test results were in disagreement with the documented stream conditions $40.3 \%$ and $50.7 \%$ of the time, respectively. This disagreement between the WET method and the instream conditions points out the inability of the test to predict the effect of an effluent on the receiving stream, and points to the need for an alternate species that will increase predictability. 
The evaluation of the current toxicity method would not be complete without considering the variability and reliability of the test method. The variability has been evaluated by several studies subjecting the method to multilaboratory verification by analyzing both reference toxicants and lab blanks (Degraeve et al. 1992, Warren-Hick and Parkhurst 1992, USEPA 1994). EPA's own chronic toxicity method (USEPA 1994) cites such a study that states "Of the 116 tests planned, 91 were successfully initiated, and 70 (77\%) met the survival and reproduction criteria for acceptability of the results (80\% survival and nine young per initial female). If the reproduction criteria of 15 young/female, used in this edition of the method, had been applied to the results of the interlaboratory study, 22 additional tests would have been unacceptable." The percentage failure for this study based on criteria to which SRS is held accountable would be $47 \%$. These results are substantiated in a study (Moore et al. 1998) which compared results from 25 toxicity analyses run by 17 laboratories. Blank samples were sent to each lab for WET testing. The laboratories reported a 35\% failure rate for the samples analyzed that, unknown to them, were method blanks. These problems were recognized in EPA's method manual (USEPA 1994) where it states "The accuracy of toxicity tests cannot be determined." It seems very doubtful that a regulatory agency would accept an SRS submittal for a method on chemical analysis that had a failure rate of $35 \%$ to $45 \%$.

\section{PROPOSED ALTERNATE SPECIES}

Exercising a special condition in the 1996 NPDES permit, SRS submitted a proposal to SCDHEC in July 1998 for the use of an alternate species in toxicity tests. The alternate species proposed is Daphnia ambigua, a native species to the southeastern coastal plain (Specht and Harmon 1997). D. ambigua is a reasonable alternative to $C$. dubia and is as sensitive or more sensitive to chronic and some acute reference toxicants. However, with some acute reference toxicants, $D$. ambigua has some loss of sensitivity. Also, the SRS study shows that one of the advantages of using $D$. ambigua is its ability to survive and reproduce well in very low hardness water, which occurs at SRS. The use of $D$. ambigua along with receiving water control or soft water simulant control water would reduce variability in the WET method by eliminating the toxic response to naturally occurring conditions, thereby revealing effluent induced toxicity.

On January 5, 1999, in accordance with the procedure described in the 40 CFR 136, SCDHEC submitted the proposal by letter to EPA for consideration and evaluation. EPA, to date, has not issued an opinion on the alternate species. EPA is waiting on internal guidance for handling alternate species. The use of $D$. ambigua would be in addition to $C$. dubia. An additional species would afford the Site flexibility in implementing the toxicity requirements. This flexibility would allow the most appropriate test method to be used on an outfall-by-outfall basis. For example, outfall G10 has not had any difficulty using $C$. dubia as the test organism. The failures at G-10 appear to be the result of a real toxicant coming through the facility. Being allowed to 
use $C$. dubia could be cost-effective, since the alternate species has a longer test period and will have to be cultured specifically for SRS. The option to use either species should be left up to the facility and be determined on site-specific basis at each outfall.

\section{OUTSIDE CONCERNS}

Concern that the WET test is not reliable or accurate is not limited to SRS. The Society of Environmental Toxicology and Aquatic Chemistry devoted an entire symposium to discussions of variability and predictability of the whole effluent toxicity testing (Grothe et al. 1996). The South Carolina Chamber of Commerce expressed its concerns with WET testing and its application in NPDES permitting in written comments on SCDHEC's Toxic Control Strategy (Applied Technology \& Engineering 1999). These concerns are also addressed in a settlement agreement between EPA, Edison Electric, and the Western Coalition of Arid States (Edison Electric et al. 1998), wherein EPA has agreed to reevaluate the WET method, run variability tests, evaluate the use of alternate tests, evaluate the use of native organisms, and evaluate the interpretation of test results. Further evidence of the concern over the validity and reliability of the test is shown by the willingness of Congress to introduce House bill HR 155. This bill addresses the use of the WET method and how to make it more representative of the actual effect of the discharge on the receiving stream by taking into account the natural variability of the species. This bill specifically states that a test failure would not be a violation for public owned treatment works.

\section{SRS POSITION/PROPOSAL}

Based on the data evaluated and literature reviewed, SRS does not believe that the WET method, in its present form, is reliable or valid for use as a regulatory limit. EPA essentially admits this in the chronic toxicity method (USEPA 1994) where it states that the accuracy of the toxicity test cannot be determined. At the time the present permit was negotiated (1994-1996), most of the technical information presented herein was not available and could not be presented in the permit negotiations. In addition, SRS was unsure of the impacts of toxicity testing. Until such time as the faults in the method are corrected, adjustments made for variability in receiving streams, and development and approval of the alternate test method has been completed, SRS strongly recommends that the WET results generated by the present method be treated as a monitor and report in the NPDES Discharge Monitoring Report.

Modifications to the WET test method are needed to address the shortfalls in the current protocol. SRS could assist in the development of such modifications to render the test method more suitable for use in areas with very soft water, such as the southeastern coastal plain. The approach would be to use an alternate species, such as D. ambigua, 
that can survive in low hardness water, to use receiving stream or similar synthetic water for control and dilution purposes, and to encompass serial dilution testing, such as $25 / 40$ and/or flow proportional options. 


\section{REFERENCES}

Applied Technology \& Engineering, 1999, Final Report: Review and Critique of the SCDHEC Toxics Control Strategy, Charlottesville, Virginia.

Degraeve, G. M., J. D. Cooney, B. H. Marsh, T. L. Pollock, N. G. Reichenbach, 1992, "Variability In The Performance Of The 7-D Ceriodaphnia-Dubia Survival And Reproduction Test - An Intralaboratory And Interlaboratory Study," Environmental Toxicology and Chemistry, 11: (6) 851-866.

Diamond, J., C. Daley, and T. Moore, 1999, Evaluating Whole Effluent Toxicity Testing as an Indicator of Instream Biological Conditions, Water Environment Research Foundation, Project 95-HHF-1, Alexandria, VA.

Edison Electric Institute v. Environmental Protection Agency, 1998, Settlement Agreement, No. 96-1062.

ETT Environmental, Inc., 1995, Fourmile Branch Surface Water at the Savannah River Site, ETT Environmental, Greenville, South Carolina.

ETT Environmental, Inc., 1998, Chronic Toxicity Identification Evaluation Tier I and Tier II of Upper Three Runs Creek, ETT Environmental, Greenville, South Carolina.

Grothe, D. R., K. L. Dickson, and D. K. Reed-Judkins (eds.), 1996, Whole Effluent Toxicity Testing: An Evaluation of Methods and Prediction of Receiving Stream Impacts, SETAC Press, Pensacola, Florida.

Hem, J. D., 1985, Study and Interpretation of the Chemical Characteristics of Natural Water, United States Geological Survey Water-Supply Paper 2254.

Moore, T., S. V. Canton, and M. R. Grimes, 1995, Developing a Method Detection Limit for Whole Effluent Toxicity Tests Using Ceriodaphnia dubia, Risk Sciences, Brentwood, Tennessee.

Morse, J. C., 1999, Aquatic Macroinvertebrate Surveys in Upper Three Runs Creek and Pen Branch, Final Report, Clemson University, Clemson, South Carolina.

Parkhurst, B. R., 1996, "Prediction Receiving Systems Impacts from Effluent Toxicity," in Grothe, D. R., K. L. Dickson, and D. K. Reed-Judkins (eds.), Whole Effluent Toxicity Testing: An Evaluation of Methods and Prediction of Receiving Stream Impacts, SETAC Press, Pensacola, Florida. 


\section{REFERENCES (cont'd)}

Rand, G. M., and S. R. Petrocelli, 1999, Fundamentals of Aquatic Toxicology: Methods and Application, Hemisphere Publishing Corporation, 666p, Washington, D.C.

Specht, W. L., 1995, Reproductive Success and Mortality Rates of Ceriodaphnia dubia Maintained in Water from Upper Three Runs, Pen Branch, and Fourmile Branch, WSRC-TR-95-0005, Westinghouse Savannah River Company, Aiken, South Carolina.

Specht, W. L., and S. M. Harmon, 1999, Evaluation of Daphnia ambigua for Routine Aquatic Toxicity Testing at the Savannah River Site (U), WSRC-TR-97-00311, Westinghouse Savannah River Company, Aiken, South Carolina.

Specht, W. L., and R. W. Kelley, 1998, Toxicity in a Blackwater Stream Caused by Naturally Occurring Iron, Presented at the $19^{\text {th }}$ Annual Meeting of the Society of Environmental Toxicology and Chemistry, Charlotte, North Carolina.

Specht, W. L., and M. Paller, 1998, Instream Biological Assessment of NPDES Point Source Discharges at the Savannah River Site, 1997-1998, WSRC-TR-98-00321, Westinghouse Savannah River Company, Aiken, South Carolina.

USEPA (United States Environmental Protection Agency), 1994, Short-Term Methods for Estimating the Chronic Toxicity of Effluents and Receiving Waters to Freshwater Organisms, EPA-600-4-91-002, Third Edition, U. S. Environmental Protection Agency, Office of Research and Development, Cincinnati, Ohio.

Warren-Hicks, W., and H. B. Parkhurst, 1992, "Performance Characteristics of Effluent Toxicity Tests: Variability and Its Implications for Regulatory Policy", "Environmental Toxicology and Chemistry 11:(6) 793-804. 
Attachment A

WSRC-RP-99-00868

A-01 TOXICITY RESULTS

CONTROL

\begin{tabular}{|c|c|c|c|c|c|}
\hline MONTH & \#ADULT & \# DEAD & MEAN & VARIANCE & \\
\hline Oct-96 & 20 & 0 & N/A & N/A & $\mathrm{lab}$ \\
\hline Nov-96 & 20 & 1 & 4.40 & 4.67 & $\mathrm{lab}$ \\
\hline Dec-96 & 20 & 0 & 5.15 & 0.98 & $\mathrm{Tab}$ \\
\hline Jan-97 & 20 & 0 & 0.00 & 0.00 & U3T \\
\hline Feb-97 & 20 & 0 & 0.02 & 0.24 & U3T \\
\hline Mar-97 & 20 & 0 & 0.00 & 0.00 & U3T \\
\hline Mar-97 & 20 & 2 & 7.65 & 21.29 & U3T \\
\hline Mar-97 & 20 & 0 & 0.00 & 0.00 & U3T \\
\hline Apr-97 & 20 & 0 & 0.00 & 0.00 & U3T \\
\hline May-97 & 20 & 0 & 0.00 & 0.00 & U3T \\
\hline Jun-97 & 20 & 2 & 13.60 & 71.72 & U3T \\
\hline Jul-97 & 20 & 0 & 0.00 & 0.00 & U3T \\
\hline Aug-97 & 20 & 1 & 0.00 & 0.00 & U3T \\
\hline Sep-97 & 20 & 3 & 0.00 & 0.00 & $\overline{\text { U3T }}$ \\
\hline Oct-97 & 20 & 0 & 0.00 & 0.00 & U3T \\
\hline Nov-97 & 20 & 3 & 9.10 & 49.67 & U3T \\
\hline Dec-97 & 20 & 1 & 8.75 & 37.25 & $\overline{\mathrm{U} 3 \mathrm{~T}}$ \\
\hline $\operatorname{Jan}-98$ & 20 & 0 & 14.25 & 107.98 & $\overline{\mathrm{U} 3 \mathrm{~T}}$ \\
\hline Feb-98 & 20 & 6 & 3.90 & 24.94 & U3T \\
\hline Mar-98 & 20 & 20 & 0.00 & 0.00 & U3T \\
\hline Apr-98 & 20 & 0 & 0.00 & 0.00 & U3T \\
\hline Apr-98 & 20 & 0 & 15.70 & 194.13 & $\mathrm{lab}$ \\
\hline May-98 & 20 & 6 & 5.90 & 34.81 & U3T \\
\hline May-98 & 20 & 1 & 30.16 & 17.92 & $\mathrm{lab}$ \\
\hline Jun-98 & 20 & 1 & 13.84 & 31.40 & U3T \\
\hline Jun-98 & 20 & 0 & 23.25 & 14.62 & $\mathrm{lab}$ \\
\hline Jul-98 & 20 & 2 & 6.80 & 35.43 & U3T \\
\hline Jul-98 & 20 & 2 & 25.35 & 35.50 & $\mathrm{lab}$ \\
\hline Aug-98 & 20 & 1 & 9.05 & 38.89 & U3T \\
\hline Aug-98 & 20 & 1 & 18.35 & 64.35 & $\mathrm{lab}$ \\
\hline Sep-98 & 20 & 20 & 0.95 & 2.37 & U3T \\
\hline Sep-98 & 20 & 3 & 15.20 & 110.59 & $1 a b$ \\
\hline Oct-98 & 20 & 10 & 0.35 & 1.19 & U3T \\
\hline Oct-98 & 20 & 1 & 16.95 & 38.04 & lab \\
\hline Nov-98 & 20 & 12 & 2.00 & 15.90 & U3T \\
\hline Nov-98 & 20 & 4 & 12.79 & 100.28 & $\mathrm{lab}$ \\
\hline Dec-98 & 20 & 6 & 1.85 & 6.03 & U3T \\
\hline Dec-98 & 20 & 1 & 19.90 & 39.25 & $\mathrm{lab}$ \\
\hline Jan-99 & 20 & 1 & 7.00 & 69.16 & U3T \\
\hline Jan-99 & 20 & 1 & 22.65 & 75.81 & $l a b$ \\
\hline Feb-01-99 & 10 & 0 & 19.80 & 10.18 & lab \\
\hline Fob-08-99 & 10 & 0 & 22.30 & 4.46 & $\mathrm{lab}$ \\
\hline Mar-08-99 & 20 & 0 & 25.25 & 98.94 & lab \\
\hline Apr-14-99 & 20 & 3 & 23.37 & 107.91 & U3T \\
\hline Apr-14-99 & 20 & 2 & 14.65 & 177.08 & $\mathrm{lab}$ \\
\hline May-11-99 & 20 & 2 & 7.15 & & U3T \\
\hline May-11-99 & 20 & 1 & 15.84 & & $\mathrm{lab}$ \\
\hline Jun-99 & 20 & 20 & 0.00 & 0.00 & U3T \\
\hline Jun-99 & 20 & 0 & 28.70 & 37.91 & $\mathrm{lab}$ \\
\hline Jul-99 & 20 & 0 & 13.05 & $\mathrm{~N} / \mathrm{A}$ & U3T \\
\hline Jul-99 & 20 & 4 & $1.7 / 15.0^{\circ}$ & N/A & $\mathrm{ab}$ \\
\hline
\end{tabular}

EFFLUENT

\begin{tabular}{|c|c|c|c|c|}
\hline \# ADULT & \# DEAD & MEAN & VARIANCE & $\mathbf{P} / \mathbf{F}$ \\
\hline 20 & 20 & N/A & N/A & $F^{*}$ \\
\hline 20 & 17 & 0.00 & 0.00 & $F^{*}$ \\
\hline 20 & 18 & 0.00 & 0.00 & $F^{*}$ \\
\hline 20 & 12 & 0.00 & 0.00 & $F^{* *}$ \\
\hline 20 & 14 & 3.60 & 3.62 & $F^{* *}$ \\
\hline 20 & 20 & 0.00 & 0.00 & $F^{* *}$ \\
\hline 20 & 1 & 13.50 & 66.99 & $P^{ \pm *}$ \\
\hline 20 & 15 & 0.00 & 0.00 & $F^{* *}$ \\
\hline 20 & 12 & 0.00 & 0.00 & $F^{* \prime \prime}$ \\
\hline 20 & 18 & 0.00 & 0.00 & $F^{* *}$ \\
\hline 20 & 7 & 5.42 & 43.59 & $F^{* *}$ \\
\hline 20 & 19 & 0.00 & 0.00 & $F^{* *}$ \\
\hline 20 & 20 & 0.00 & 0.00 & $F^{* *}$ \\
\hline 20 & 18 & 0.00 & 0.00 & $F^{* *}$ \\
\hline 20 & 20 & 0.00 & 0.00 & $F^{\star \star \star}$ \\
\hline 20 & 0 & 15.85 & 75.19 & $P^{* *}$ \\
\hline 20 & 9 & 4.50 & 19.00 & $F^{* \star}$ \\
\hline 20 & 5 & 12.10 & 87.98 & $F^{* *}$ \\
\hline 20 & 3 & 4.90 & 27.35 & $P^{* \star *}$ \\
\hline 20 & 3 & 17.79 & 60.73 & $P^{n \star \hbar}$ \\
\hline 20 & 16 & 0.00 & 0.00 & $F^{* \pm}$ \\
\hline 20 & 5 & 6.25 & 6.25 & $F$ \\
\hline 20 & 20 & 0.00 & 0.00 & invalid \\
\hline 20 & 20 & 0.00 & 0.00 & $F$ \\
\hline 20 & 20 & 0.00 & 0.00 & invalid \\
\hline 20 & 20 & 0.00 & 0.00 & $F$ \\
\hline 20 & 20 & 0.00 & 0.00 & invalid \\
\hline 20 & 20 & 0.00 & 0.00 & $F$ \\
\hline 20 & 20 & 0.00 & 0.00 & invalid \\
\hline 20 & 20 & 0.00 & 0.00 & $F$ \\
\hline 20 & 19 & 0.00 & 0.00 & invalid \\
\hline 20 & 20 & 0.00 & 0.00 & $F$ \\
\hline 20 & 12 & 0.00 & 0.00 & invalid \\
\hline 20 & 20 & 0.00 & 0.00 & $F$ \\
\hline 20 & 20 & 0.00 & 0.00 & invalid \\
\hline 20 & 15 & 0.00 & 0.00 & $F$ \\
\hline 20 & 20 & 0.00 & 0.00 & invalid \\
\hline 20 & 20 & 0.00 & 0.00 & $F$ \\
\hline 20 & 20 & 2.55 & 4.89 & invalid \\
\hline 20 & 10 & 16.50 & 49.84 & $F$ \\
\hline 10 & 10 & 7.00 & 10.44 & $\bar{F}$ \\
\hline 10 & 9 & 7.50 & 29.39 & $\bar{F}$ \\
\hline 20 & 20 & 1.30 & 4.43 & $\bar{F}$ \\
\hline 20 & 20 & & & $\mathbf{F}$ \\
\hline 20 & 20 & 1.35 & 3.29 & $F$ \\
\hline 20 & 1 & 13.15 & & invalid \\
\hline 20 & 1 & 22.40 & & $P$ \\
\hline 20 & 19 & 1.85 & 18.97 & $F$ \\
\hline 20 & 0 & 21.75 & 59.88 & $F$ \\
\hline 20 & 20 & 0.00 & $N / A$ & $\bar{F}$ \\
\hline 20 & 17 & N/A & N/A & $F$ \\
\hline
\end{tabular}

$F^{*}=$ UTR water used only for dilution water;

$P^{* *}=$ effluent mean is greater than control mean, but the test is invalid due to low reproduction in the control $F^{\star *}=$ failure due to lack of min criteria 


\section{A-11 TOXICITY RESULTS}

CONTROL

\begin{tabular}{|c|c|c|c|c|c|}
\hline MONTH & \# ADULT & \# DEAD & MEAN & VARIANCE & \\
\hline Oct-96 & 20 & 0 & 22.00 & 24.41 & lab \\
\hline Nov-96 & 20 & 1 & 21.45 & 68.57 & lab \\
\hline Dec-96 & 20 & 0 & 25.40 & 13.94 & lab \\
\hline Jan-97 & 20 & 0 & 12.95 & 50.37 & U3T \\
\hline Feb-97 & 20 & 9 & 5.65 & 26.66 & U3T \\
\hline Mar-97 & 20 & 1 & 10.25 & 24.30 & U3T \\
\hline Apr-97 & 20 & 0 & 18.18 & 22.53 & U3T \\
\hline May-97 & 20 & 11 & 4.33 & 10.36 & U3T \\
\hline Jun-97 & 20 & 5 & 7.80 & 31.33 & U3T \\
\hline Jul-97 & 20 & 11 & 6.80 & 23.85 & U3T \\
\hline Aug-97 & 20 & 5 & 5.05 & 31.27 & U3T \\
\hline Sep-97 & 20 & 8 & 8.68 & 45.67 & U3T \\
\hline Oct-97 & 20 & 9 & 8.05 & 24.36 & $\overline{\mathrm{U} 3 \mathrm{~T}}$ \\
\hline Nov-97 & 20 & 3 & 5.10 & 44.21 & U3T \\
\hline Dec-97 & 20 & 5 & 6.05 & 11.00 & U3T \\
\hline Jan-98 & 20 & 0 & 14.55 & 127.85 & U3T \\
\hline Feb-98 & 20 & 8 & 2.45 & 15.10 & U3T \\
\hline Mar-98 & 20 & 20 & 0.00 & 0.00 & U2T \\
\hline Apr-98 & 20 & 4 & 1.67 & 11.76 & U3T \\
\hline Apr-98 & 20 & 0 & 23.30 & 81.70 & $\mathrm{lab}$ \\
\hline May-98 & 20 & 1 & 5.10 & 14.62 & U3T \\
\hline May-98 & 20 & 1 & 25.44 & 29.44 & $\mathrm{lab}$ \\
\hline Jun-98 & 20 & 0 & N/A & N/A & U3T \\
\hline Jun-98 & 20 & 1 & 25.44 & 29.44 & $\mathrm{lab}$ \\
\hline Jul-98 & 20 & 1 & 8.05 & 29.94 & U3T \\
\hline Jul-98 & 20 & 2 & 17.68 & 76.90 & lab \\
\hline Aug-98 & 20 & 4 & 6.20 & 13.75 & U3T \\
\hline Aug-98 & 20 & 1 & 15.95 & 55.74 & $\mathrm{lab}$ \\
\hline Sep-98 & 20 & 4 & 18.55 & 139.62 & $\mathrm{lab}$ \\
\hline Oct-98 & 20 & 17 & 0.00 & 0.00 & U3T \\
\hline Oct-98 & 20 & 2 & 18.10 & 81.67 & lab. \\
\hline Nov-98 & 20 & 12 & 2.00 & 15.90 & U3T \\
\hline Nov-98 & 20 & 4 & 12.79 & 100.28 & $\mathrm{lab}$ \\
\hline Dec-98 & 20 & 0 & 18.05 & 62.16 & $\mathrm{lab}$ \\
\hline Jan-99 & 20 & 0 & 23.90 & 62.20 & $1 a b$ \\
\hline Feb-99 & 20 & 0 & 21.50 & 5.42 & lab \\
\hline Mar-99 & 20 & 1 & 21.60 & 7.63 & $\mathrm{lab}$ \\
\hline Mar-99 & 20 & 0 & 24.50 & 5.21 & $\mathrm{lab}$ \\
\hline Mar-99 & 20 & 0 & 25.30 & 8.33 & $\mathrm{lab}$ \\
\hline Apr-99 & 20 & 2 & 23.37 & 107.91 & lab \\
\hline May-99 & 20 & 4 & 13.50 & 100.80 & lab \\
\hline Jun-99 & 20 & 0 & 23.85 & 45.19 & $\mathrm{lab}$ \\
\hline Jul-99 & 20 & 4 & $11.7 / 15^{*}$ & 109.20 & lab \\
\hline
\end{tabular}

$F^{*}$ and $P^{*}=$ UTR water used only for dilution water

$P^{* \star}=$ effluent mean is greater than control mean, but the test is invalid due to low reproduction in the control

$F^{\star *}=$ failure due to lack of min criteria
EFFLUENT

\begin{tabular}{|c|c|c|c|c|}
\hline \# ADULT & \# DEAD & MEAN & VARIANCE & P/F \\
\hline 20 & 2 & 19.10 & 35.15 & $P^{*}$ \\
\hline 20 & 6 & 12.79 & 76.84 & $F^{*}$ \\
\hline 20 & 0 & 19.20 & 33.50 & $F^{*}$ \\
\hline 20 & 0 & 17.35 & 73.50 & $P *$ \\
\hline 20 & 4 & 9.95 & 30.47 & $P^{* *}$ \\
\hline 20 & 4 & 16.30 & 76.21 & $P^{*+1}$ \\
\hline 20 & 0 & 23.26 & 33.76 & $P$ \\
\hline 20 & 3 & 13.79 & 24.07 & $P^{* *}$ \\
\hline 20 & 1 & 16.85 & 14.87 & $P^{* *}$ \\
\hline 20 & 0 & 16.00 & 41.28 & $P^{* *}$ \\
\hline 20 & 1 & 17.95 & 44.89 & $\overline{P=*}$ \\
\hline 20 & 1 & 19.95 & 84.58 & $P * *$ \\
\hline 20 & 10 & 10.45 & 27.73 & $P^{* *}$ \\
\hline 20 & 1 & 18.60 & 79.41 & $P^{* *}$ \\
\hline 20 & 0 & 11.15 & 6.24 & $P^{* *}$ \\
\hline 20 & 0 & 14.35 & 44.02 & $\mathbf{P}$ \\
\hline 20 & 0 & 8.80 & 45.43 & 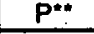 \\
\hline 20 & 1 & 24.15 & 59.67 & $P^{* *}$ \\
\hline 20 & 2 & 8.17 & 91.32 & invalid \\
\hline 20 & 0 & 9.45 & 29.42 & $F$ \\
\hline 20 & 1 & 5.89 & 29.21 & invalid \\
\hline 20 & 1 & 16.17 & 45.91 & $F$ \\
\hline 20 & 13 & 0.00 & 0 & $\bar{F}$ \\
\hline 20 & 1 & 16.17 & 45.91 & $F$ \\
\hline 20 & 6 & 4.80 & 23.04 & invalid \\
\hline 20 & 1 & 8.15 & 16.03 & $F$ \\
\hline 20 & 4 & 0.75 & 3.67 & invalid \\
\hline 20 & 3 & 3.00 & 6.84 & $F$ \\
\hline 20 & 7 & 16.45 & 81 & $\mathbf{P}$ \\
\hline 20 & 17 & 0.00 & 이 & invalid \\
\hline 20 & 15 & 3.50 & 10.16 & $F$ \\
\hline 20 & 13 & 0.00 & 이 & invalid \\
\hline 20 & 11 & 2.65 & 11.61 & $F$ \\
\hline 20 & 2 & 13.25 & 42.61 & $F$ \\
\hline 20 & 5 & 12.15 & 76.67 & $F$ \\
\hline 20 & 1 & 11.30 & 9.27 & $F$ \\
\hline 20 & 0 & 19.70 & 3.80 & $\bar{F}$ \\
\hline 20 & 0 & 21.90 & 5.88 & $F$ \\
\hline 20 & 2 & 18.10 & 42.79 & $\mathbf{F}$ \\
\hline 20 & 1 & 17.75 & 79.78 & $\bar{F}$ \\
\hline 20 & 7 & 15.30 & 147.3 & $\bar{P}$ \\
\hline 20 & 0 & 23.90 & 46.62 & $\bar{P}$ \\
\hline 20 & 0 & 17.00 & 78.50 & $P$ \\
\hline
\end{tabular}

adult 
Attachment $\mathrm{C}$

\section{G-10 Toxicity Data}

\begin{tabular}{|c|c|c|c|c|c|c|c|c|c|c|c|c|c|c|c|c|c|}
\hline Date & $\begin{array}{c}\text { Toxiclity } \\
\text { (PassfFail) }\end{array}$ & Zinc (mgl) & $\begin{array}{c}\text { Copper } \\
\text { (mgl) }\end{array}$ & $\begin{array}{c}\text { Al } \\
(m g h)\end{array}$ & $\begin{array}{c}\text { Barium } \\
(\mathrm{mg} / \mathrm{L})\end{array}$ & $\begin{array}{c}\text { Beryllium } \\
\text { (mgh) }\end{array}$ & $\begin{array}{l}\text { Calcium } \\
\text { (mgh) }\end{array}$ & $\begin{array}{l}\text { Chromium } \\
\text { (mol) }\end{array}$ & $\begin{array}{l}\text { Iron } \\
\text { (mol) }\end{array}$ & $\begin{array}{c}\mathrm{Pb} \\
(\mathrm{mgl})\end{array}$ & $\left|\begin{array}{c}\mathrm{Mg} \\
(\mathrm{mg} /)\end{array}\right|$ & $\left|\begin{array}{c}M n \\
(m g h)\end{array}\right|$ & $\mid \begin{array}{c}\mathrm{Ni} \\
(\mathrm{mol})\end{array}$ & $\begin{array}{c}K \\
(m g h)\end{array}$ & $\begin{array}{c}\text { Ag } \\
\text { (mgl) }\end{array}$ & $\begin{array}{l}\text { Sodium } \\
\text { (moll) }\end{array}$ & Chronic or Acute - compliance sample \\
\hline $01 / 07 / 1998$ & - & 0.257 & NO & & & & & & & 0.004 & & & & & & & \\
\hline $04 / 08 / 1998$ & . & 0.140 & 0.067 & & & & & & & ND & & & & & & . & \\
\hline $08 / 04 / 1998$ & Fall & $\cdot$ & & & & & & & & & & & & & & & Chronic - compliance sample \\
\hline $08 / 19 / 1998$ & Pass & - & & & & & & & & & & & & & & & \\
\hline $08 / 28 / 1998$ & Fail & $05 \%$ & 0.008 & 0.114 & 0.009 & & $1 \%$ & NO & 0.152 & ND & 1.680 & 0.015 & ND & 20.400 & ND & 122 & Acuto - compliance sample \\
\hline 10/09/1998 & Pass & 0.319 & 0.019 & ND & $0 \% 70$ & & 8.060 & 0.006 & 0.258 & ND & 1.480 & 0.009 & ND & 16 & ND & 108 & \\
\hline $10 / 11 / 1998$ & Pass & 0.318 & 0.013 & ND & 0.011 & & 8.750 & 0.016 & 0.251 & ND & 1.740 & 0.009 & \%om & 19.600 & ND & 126 & \\
\hline $09 / 06 / 1999$ & Sample set up improperly by lab & 0.390 & 0.017 & & & & & & & ND & & & & & & & \\
\hline $02 / 17 / 1999$ & Pass & 0.220 & 0.014 & 0.241 & ND & & 7.200 & ND & 0.241 & NO & 1.490 & ND & NO & $13.900 \mid$ & $\%$ & 151. & \\
\hline $02 / 18 / 1999$ & Crashed incubator & $:$ & & & & & & & & & & & & & & & \\
\hline $02 / 23 / 1999$ & Crashed Incubator & 0.311 & 0.032 & 0.168 & 0.005 & & 7.450 & ND & 0.317 & NO & 1.590 & ND & ND & 13.900 & 0.087 & 146.000 & \\
\hline $02 / 24 / 1999$ & Pass & 0.358 & 0.024 & 0.183 & 0.007 & & 7.660 & ND & 0.349 & NO & 1.630 & $\mathrm{ND}$ & ND & 15.000 & 0.086 & 149 & \\
\hline $02 / 25 / 1999$ & Pass & 0.373 & 0.029 & 0.093 & ND & & 7.380 & ND & 0.323 & ND & 1.500 & 0.006 & ND & 13.100 & 0.081 & 140 & \\
\hline $03 / 02 / 1999$ & Pass & 0.341 & 0.018 & & & & & & & & & & & & & & \\
\hline $03 / 03 / 1999$ & Failed to set up sample & 0.333 & 0.042 & 0.22 & 0.009 & & 7.14 & NO & 0.388 & 0.005 & 1.48 & 0.007 & ND & 12.2 & ND & 154 & \\
\hline 03/04/1999 & Pass & 0.424 & 0.019 & 0.209 & 0.007 & & 8.29 & ND & 0.359 & ND & 1.65 & 0.005 & ND & 13.2 & ND & 162 & \\
\hline $03 / 08 / 1999$ & Pass & 0.327 & 0.018 & 0.159 & 0.01 & & 8.04 & NO & 0.29 & ND & 1.72 & ND & ND & 13.5 & ND & 10 & \\
\hline $03 / 09 / 1999$ & Pass & 0.347 & 0.018 & 0.234 & 0.011 & ND & 8.62 & ND & 0.345 & ND & 1.84 & 0.006 & ND & 16.3 & ND & 174 & \\
\hline $03 / 11 / 1999$ & Pass & 0.459 & 0.028 & 0.154 & 0.013 & & 8.94 & NO & 0.433 & ND & 1.92 & 0.016 & ND & 15.8 & ND & 170 & \\
\hline $03 / 15 / 1999$ & Pass & 0.385 & 0.024 & ND & 0.01 & & 8.19 & ND & 0.405 & ND & 1.75 & 0.007 & ND & 6.16 & ND & 150 & Acute and Chronic - Compliance Sample \\
\hline $03 / 17 / 1999$ & Pass & 0.383 & 0.035 & 0.117 & 0.009 & & 7.45 & 0.01 & 0.388 & ND & 1.61 & 0.006 & 0.01 & 10.7 & ND & 127 & Chronic - Compliance Sample \\
\hline $03 / 19 / 1999$ & Pass & 0.434 & 0.021 & 0.187 & 0.008 & & 8.37 & ND & 0.412 & ND & 1.64 & 0.028 & ND & 12.3 & ND & 123 & Chronic-Compllance Sample \\
\hline $03 / 22 / 1999$ & Pass & 0.506 & $\%$ & ND & ND & $60 \%$ & 8.91 & ND & 0.485 & ND & 1.82 & 104 & ND & 6.13 & NO & 160 & \\
\hline $03 / 24 / 1999$ & Pass & 0.437 & 0.034 & 0.132 & 0.007 & & 8.680 & ND & 0.294 & 0.010 & 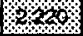 & ND & ND & $30 \%$ & ND & 160.000 & \\
\hline $03 / 29 / 1999$ & Pass & & & & & & & & & & & & & & & & \\
\hline 03/30/1999 & Pass & & & & & & & & & & & & & & & & \\
\hline $04 / 07 / 1999$ & Pass & 0.49 & 0.036 & ND & 0.01 & ND & 7.6 & ND & $1 \%$ & 0.026 & 1.6 & 0.026 & ND & 9.7 & NO & 110 & \\
\hline 04/08/1999 & Pass & 0.44 & 0.03 & NO & 0.01 & ND & 7.2 & ND & 0.39 & 0041 & 1.5 & 0.007 & ND & 8.9 & ND & 100 & \\
\hline $04 / 14 / 1999$ & Pass & 0.36 & 0.035 & 0.13 & 0.011 & ND & 6.9 & ND & 0.42 & ND & 1.6 & 0.009 & ND & 9.5 & ND & 128 & \\
\hline $04 / 15 / 1999$ & Pass & & & & & & & & & & & & & & & & \\
\hline $05 / 19 / 1999$ & Pass & 0.27 & 0.06 & 0 & 0.0075 & ND & 6.8 & 86 & 13 & NO & 1.3 & 0.031 & 6 & 11 & ND & 120 & \\
\hline $\operatorname{Max}$ & & 0.603 & 0.088 & 0.300 & 0.170 & 0.017 & 9.720 & 0.600 & 12.000 & 0.031 & 2.220 & 0.041 & 0.095 & 21.000 & 0.088 & 190.000 & \\
\hline Average & & 0.373 & 0.029 & 0.167 & 0.019 & 0.017 & 8.028 & 0.011 & 0.375 & 0.015 & 1.673 & 0.013 & 0.011 & 13.385 & 0.086 & 142.000 & \\
\hline
\end{tabular}

